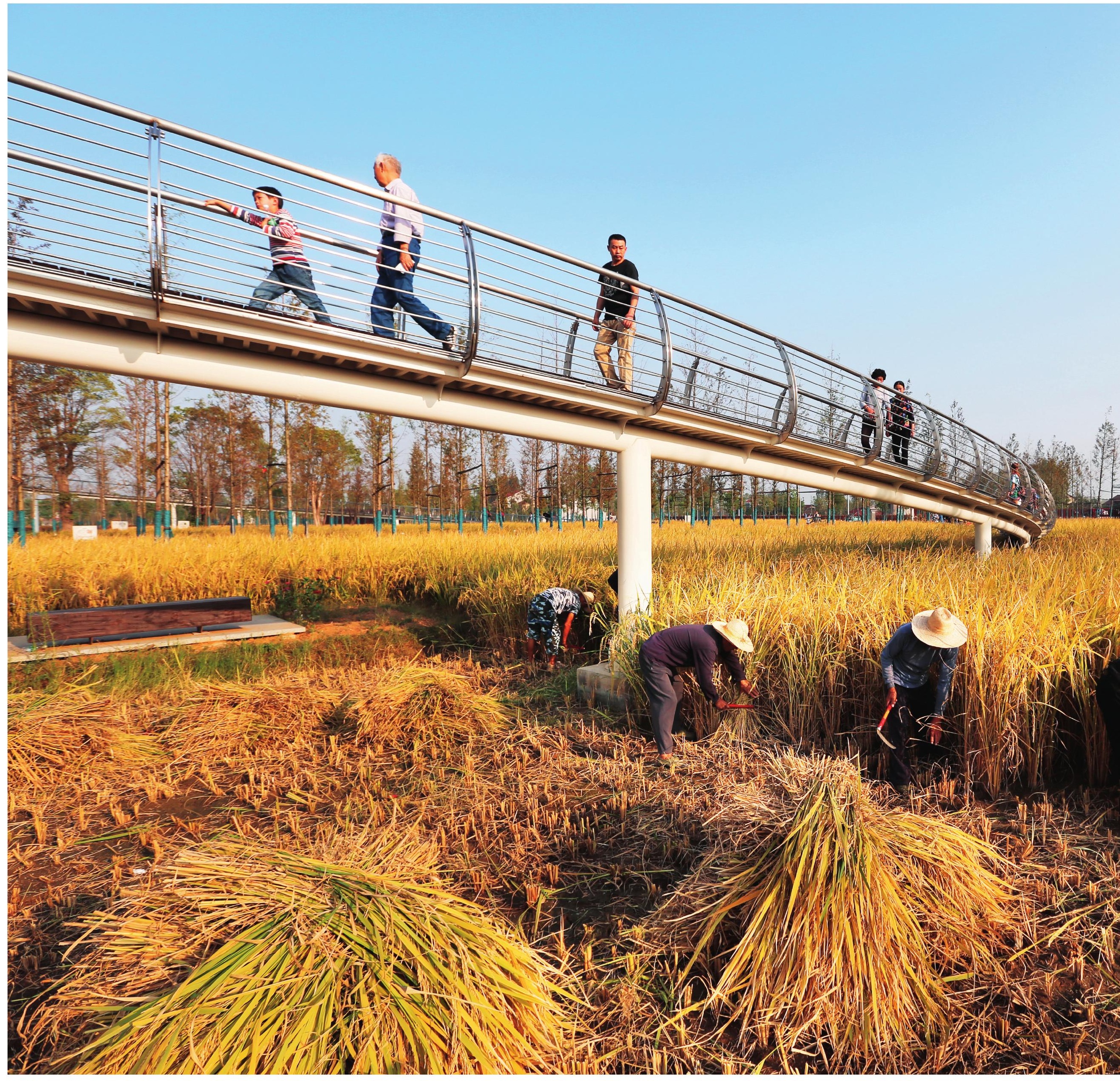




\section{运行的生产性景观: \\ 常德市城头山大遗址公园生态修复与景观设计 \\ PRODUCTIVE LANDSCAPE IN OPERATION: ECOLOGICAL RESTORATION AND LANDSCAPE DESIGN OF CHENGTOUSHAN NATIONAL ARCHAEOLOGICAL SITE PARK IN CHANGDE}

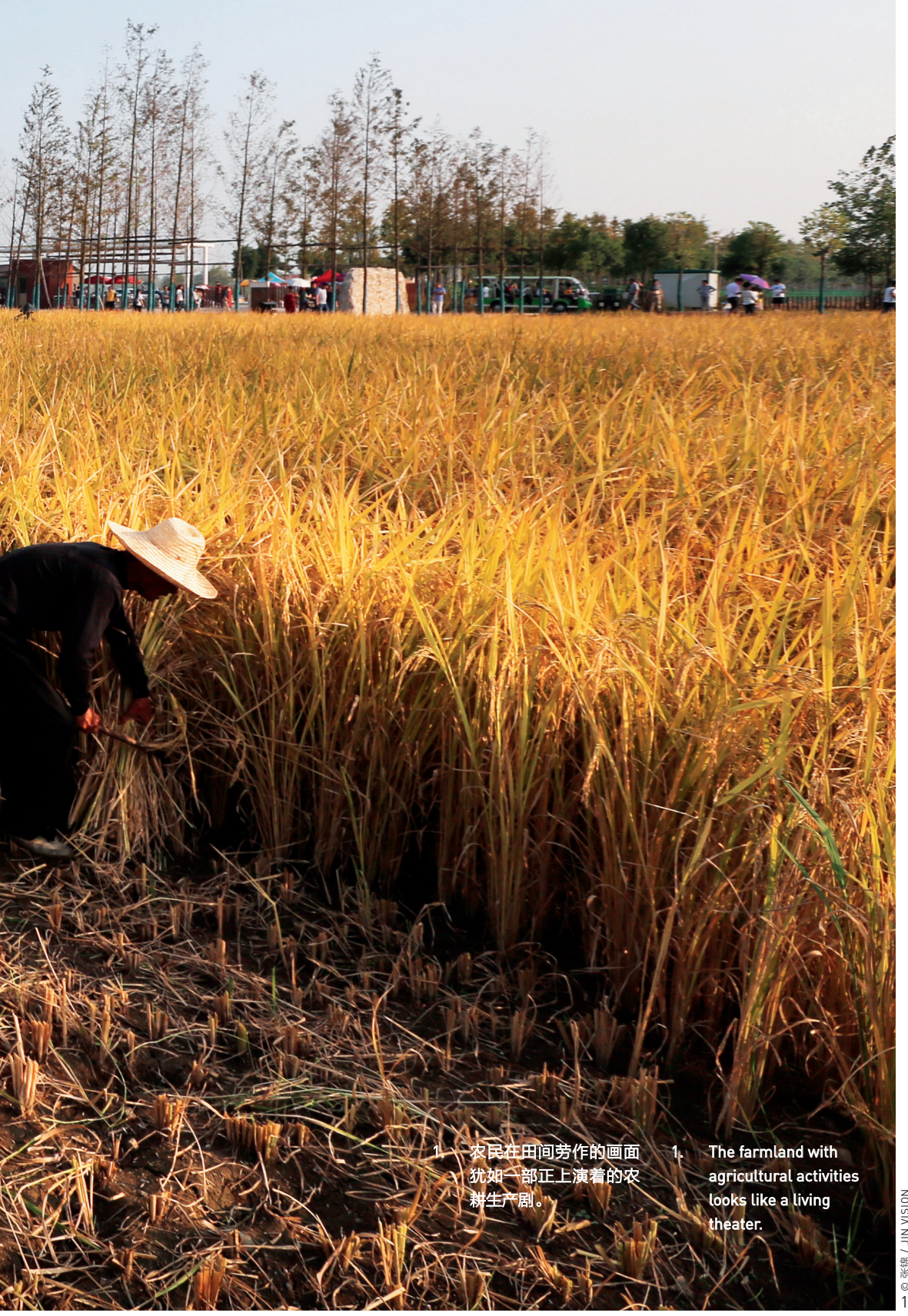

耿苯, 邵飞, 张亚奇 / Ran GENG, Fei SHAO, Yaqi ZHANG

1 项目背景

城头山国家考古遗址公园位于湖南省 澧县车溪乡城头山村的城头山遗址核心区周 边。公园依托全国重点文物保护单位城头山 遗址进行修建, 是国家级大遗址保护示范 区，具有遗址保护、文化展示和旅游休闲三 大功能。设计团队对遗址外围约 $20 \mathrm{hm}^{2}$ 的景 观进行了规划改造。

1979年以前, 城头山还是位于洞庭湖冲 积平原上的一座土丘, 当地农民在此精耕细 作, 漫山稻菽飘香。由于遗址被意外发现, 这里被鉴定为迄今为止中国最早的古城池遗 址。加之此地本就是中国水稻种植的发源 地, 不久之后城头山便被列为全国重点文物 保护单位。然而, 禁绝耕种的用地保护政策 却使得当地本就十分紧张的耕地资源更加短 缺。2014年, 在对该地块进行了长达30年的 消极保护后, 当地政府终于决定将该地区改 造为旅游景点, 以促进当地经济发展, 变负 担为福祉。

\section{2 挑战与目标}

在项目团队于2015年介入之前，城头山 考古遗址周围的农田已经转变为装饰性的景

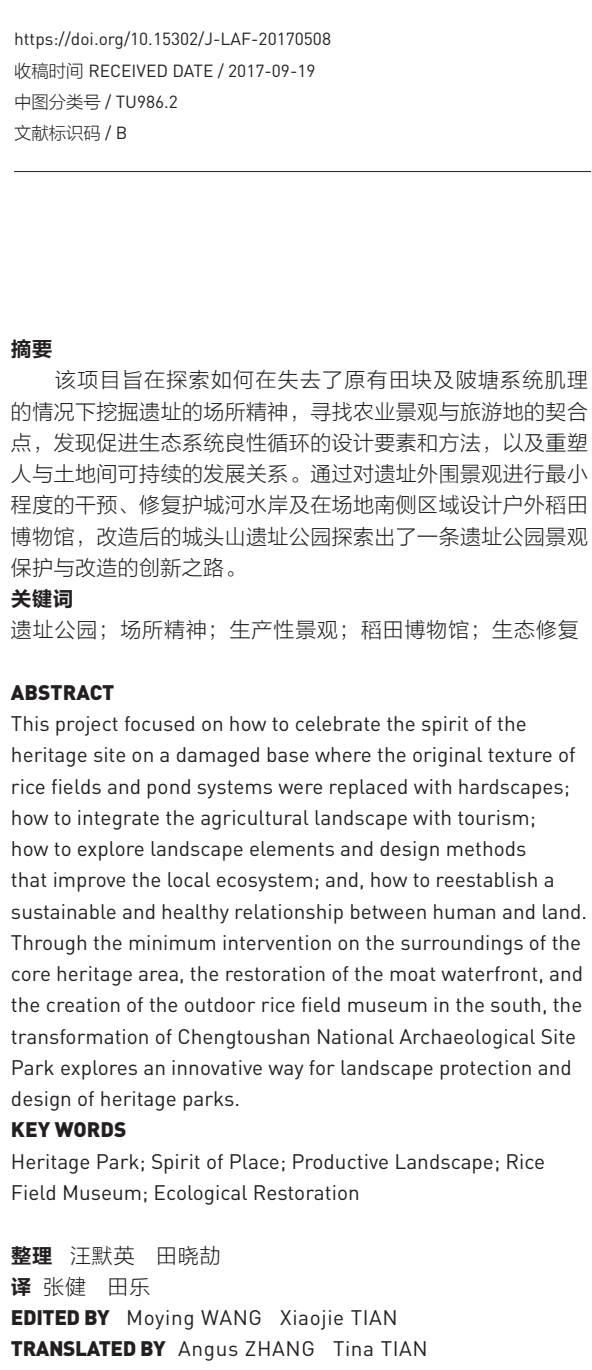
人与上地间可持续的发展关系。通过对遗址外围景观进行最小 程度的干预、修复护城河水岸及在场地南侧区域设计户外稻田 博物馆, 改造后的城头山遗址公园探索出了一条遗址公园景观 保护与改造的创新之路。

关键词

遗址公园; 场所精神; 生产性景观; 稻田博物馆; 生态修复 ABSTRACT

This project focused on how to celebrate the spirit of the heritage site on a damaged base where the original texture of rice fields and pond systems were replaced with hardscapes; how to integrate the agricultural landscape with tourism; how to explore landscape elements and design methods that improve the local ecosystem; and, how to reestablish a sustainable and healthy relationship between human and land. Through the minimum intervention on the surroundings of the core heritage area, the restoration of the moat waterfront, and the creation of the outdoor rice field museum in the south, the transformation of Chengtoushan National Archaeological Site Park explores an innovative way for landscape protection and KEY WORDS

Heritage Park; Spirit of Place; Productive Landscape; Rice Field Museum; Ecological Restoration

整理 汪默英 田晓劼

译张健 田乐

EDITED BY Moying WANG Xiaojie TIAN

TRANSLATED BY Angus ZHANG Tina TIAN 


\begin{tabular}{|c|}
\hline 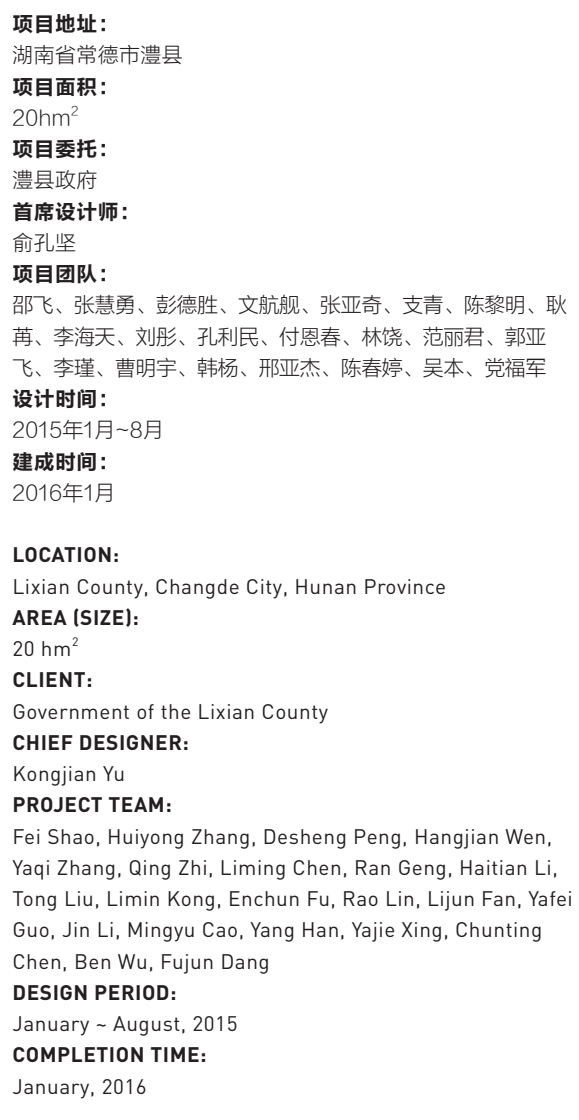 \\
\hline
\end{tabular}

观大道和广场。一条宽阔的轴线已经建成, 其上坐落着一座博物馆, 两旁排列着观赏花 木与花坛。在遗址的南入口处, 一座面积达 $2 \mathrm{hm}^{2}$ 的巨型广场正在施工中。此外, 在护城 河沿线分布着规整的滨水道路、大面积的混 凝土亲水平台, 以及修剪规整的园林植被和 人造景观石, 与附近遗址的氛围格格不入。 部分河道水体淤积、富营养化严重, 藻类等 浮游生物遍布。护城河支渠由硬质砌石构 成, 固化的护坡与生硬的岸线阻断了水体与 生态环境相融。场地失去了原有的生机, 游客 也失去了前来观赏的兴趣。

在原有装饰性景观工程被叫停后, 新 介入的设计团队对场地展开了实地调研。设 计团队发现, 对场地内已建成的景观大道进 行改造的难度很大、成本很高, 因此只得保 留; 但可以对南门广场进行重新设计。此 外, 遗址公园中大部分土地还未被平整, 曾 经的稻田肌理及农田种植土依然存在, 这为 重塑遗址周边环境、再现农业景观提供了可 能。该项目的首要挑战在于如何在开发景区 的同时, 保护、还原遗址的真实性和完整 性, 将随处可见的农业景观转变为具有吸引 力的旅游目的地。因此, 设计一座适应场所 文化背景的、生态且美观的遗址公园成为了 该项目的设计目标。

\section{3 设计策略}

设计团队对城头山遗址外围景观采取了 多样化的保护和改造策略, 以使其生态、教
育、生产、游息等多方面的效益最大化。

\section{1 护城河水岸修复}

设计团队使用抛石及仿木桩护岸, 并扞 插柳条, 用柔性的生态驳岸取代原有的硬质 砌石护岸。在河道内种植芦苇 (Phragmites australias)、干屈菜 (Lythrum salicaria)、黄菖蒲（Iris pseudacorus）、 水苾 ( Scirpus validus) 等十几种水生植 物, 使其吸附污染物质、净化水体, 为水中 的动物和昆虫提供栖居和繁衍所需的植物群 落。河岸以稻田、生产性水生植物和野草 斑块为基底, 在其间穿插下沉式或半开放 的滨水休䕀空间, 以供游客驻足停留, 观 察水鸟、欣赏古城遗址。堤岸外围延续原 有稻田肌理, 种植了水杉 (Metasequoia glyptostroboides) 林块和乌柏 (Sapium sebiferum) 林块, 不仅形成了一处处林下休 闲空间, 同时也充当了遗址与村庄、农田之 间的缓冲带, 使人为活动对遗址的干扰降至 最低。

秉持最小干预的原则, 设计团队在护城 河外围的部分水面上设置了可拆卸的玻璃钢 浮箱, 并在其上架设了距离水面30 50cm高 的木栈道, 一套与木栈道相结合的环境解说 系统贯穿其中。在护城河的环绕之下, 考古遗 址犹如一座空旷宁滥的剧院, 让人们联想起在 这里的往昔岁月。

\section{2 稻田博物馆}

场地南侧的公园主体部分重新回归农
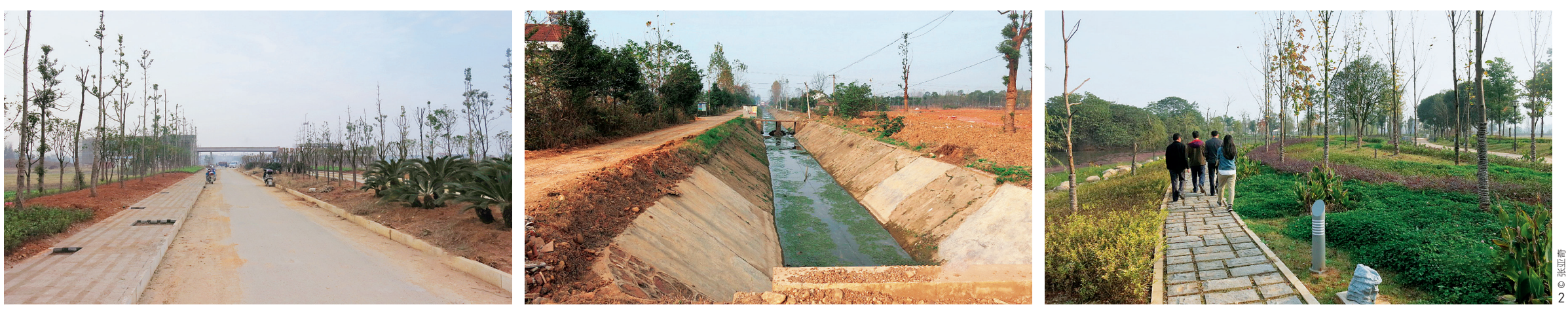
田, 成为了一个户外的稻田博物馆。农民重 新回到土地, 轮作一年两季、多品种的水稻 ( 包括稻米、䊁米、香米、小米、黄米、西 米、薏米、黑米、红米等)。作为农田景 观的有机组成部分, 水塘、水渠和湿地分 布其中, 其间生长着茂盛的生产性乡土植 被, 如荷花 (Nelumbo nucifera) 、菱角 ( Trapa bispinosa)、蒙荠 (Heleocharis dulcis )、艾白 (Zizania latifolia)、慈姑 (Sagittaria sagittifolia)、茨实 (Euryale ferox) 等。这些湿地和水系像海绵一样收 集雨水、调节旱涝, 同时过滤稻田中的污染

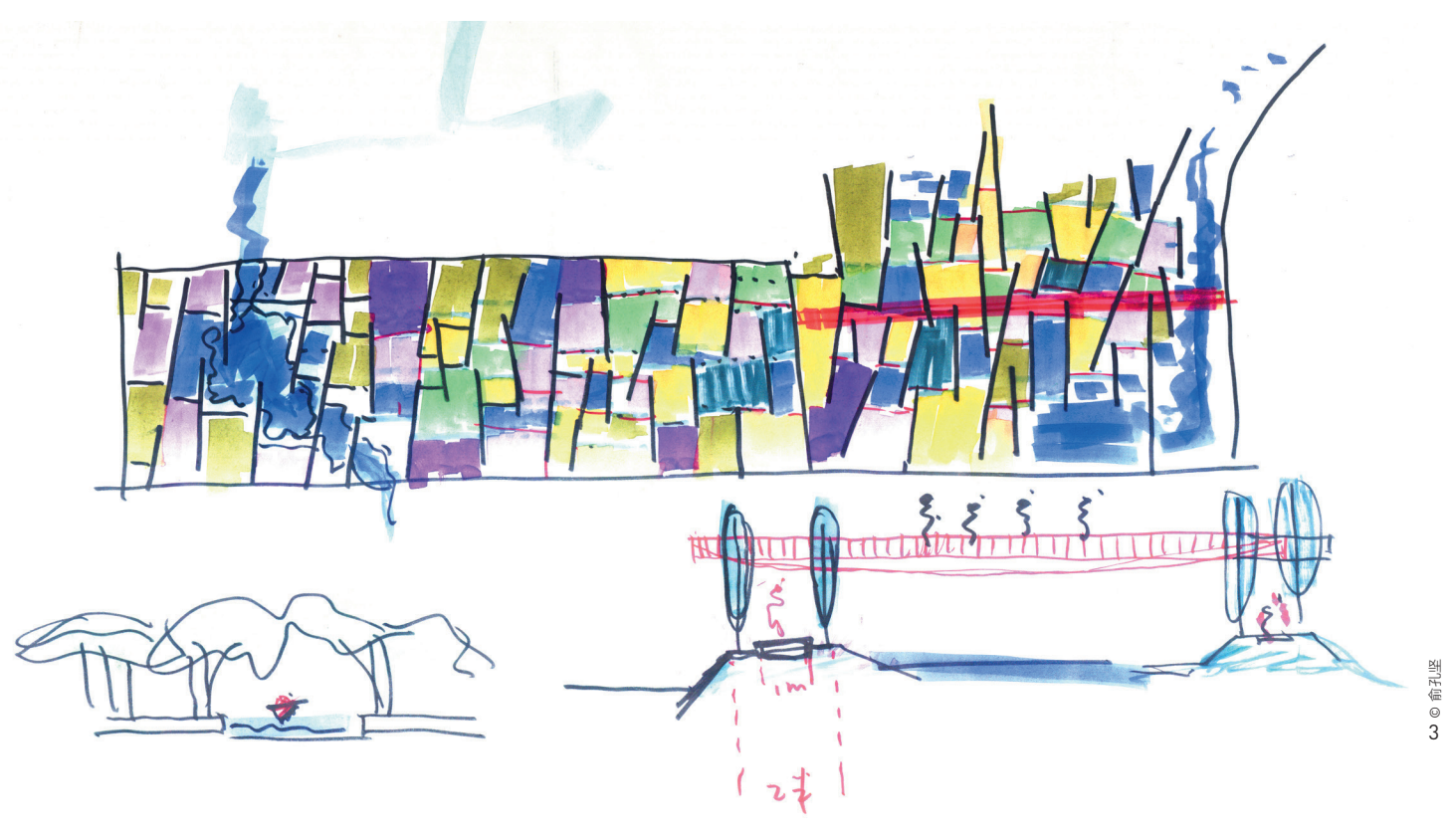

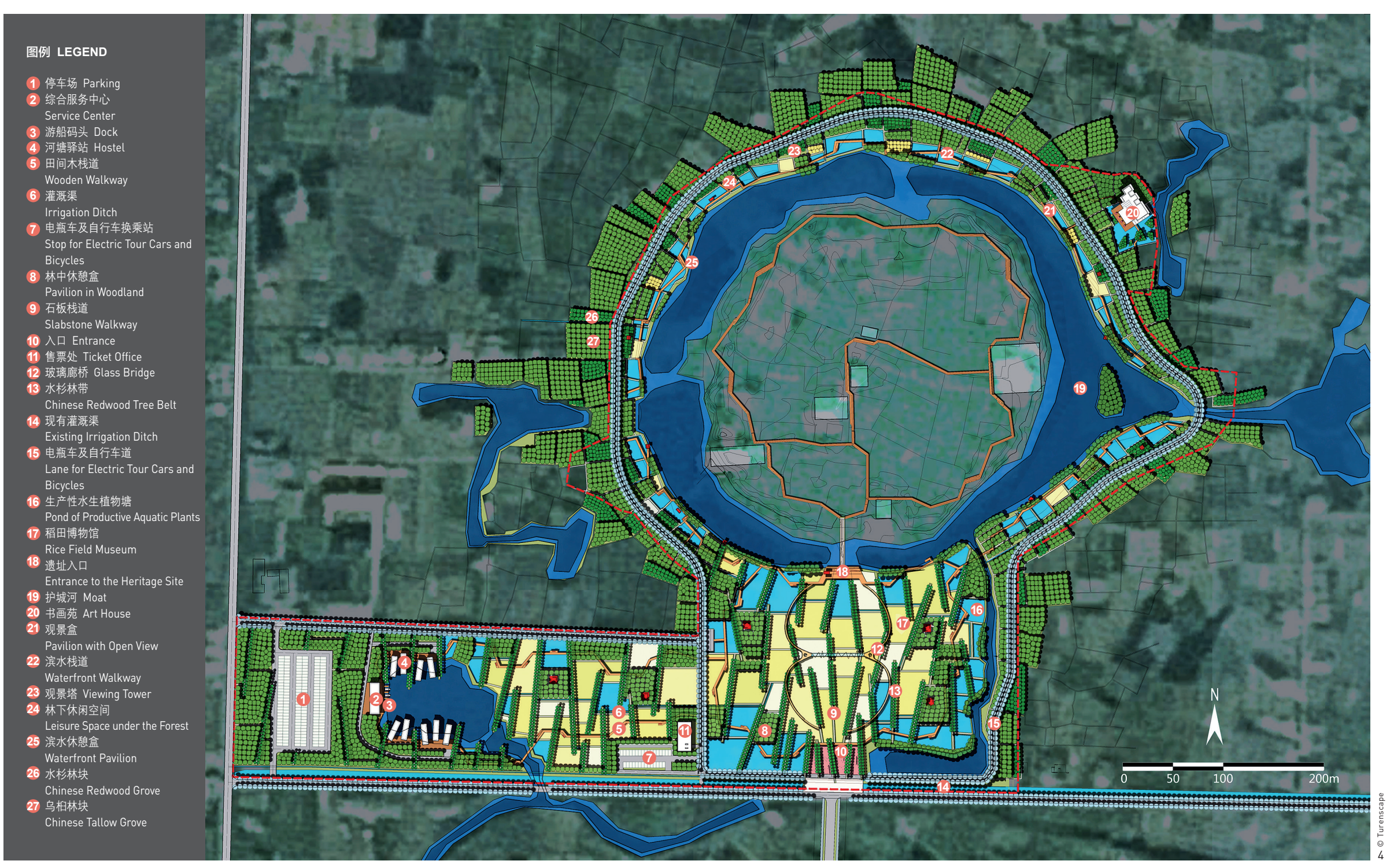



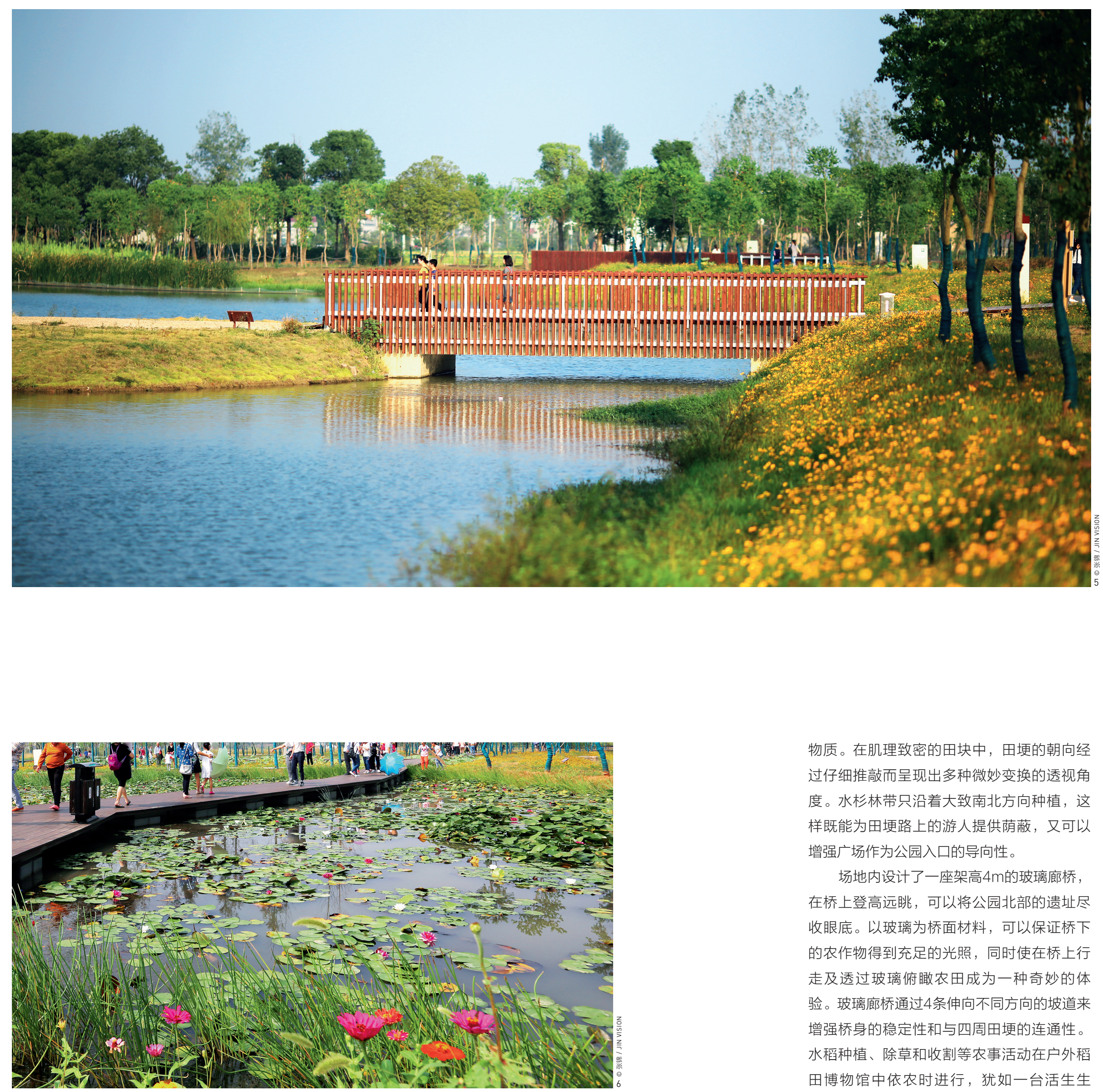

物质。在肌理致密的田块中, 田埂的朝向经 过仔细推敲而呈现出多种微妙变换的透视角 度。水杉林带只沿着大致南北方向种植, 这 样既能为田埂路上的游人提供荫蔽, 又可以 增强广场作为公园入口的导向性。

场地内设计了一座架高 $4 \mathrm{~m}$ 的玻璃廊桥, 在桥上登高远跳, 可以将公园北部的遗址尽 收眼底。以玻璃为桥面材料, 可以保证桥下 的农作物得到充足的光照, 同时使在桥上行 走及透过玻璃俯瞰农田成为一种奇妙的体 验。玻璃廊桥通过4条伸向不同方向的坡道来 增强桥身的稳定性和与四周田埂的连通性。 水稻种植、除草和收割等农事活动在户外稻 田博物馆中依农时进行, 犹如一台活生生 


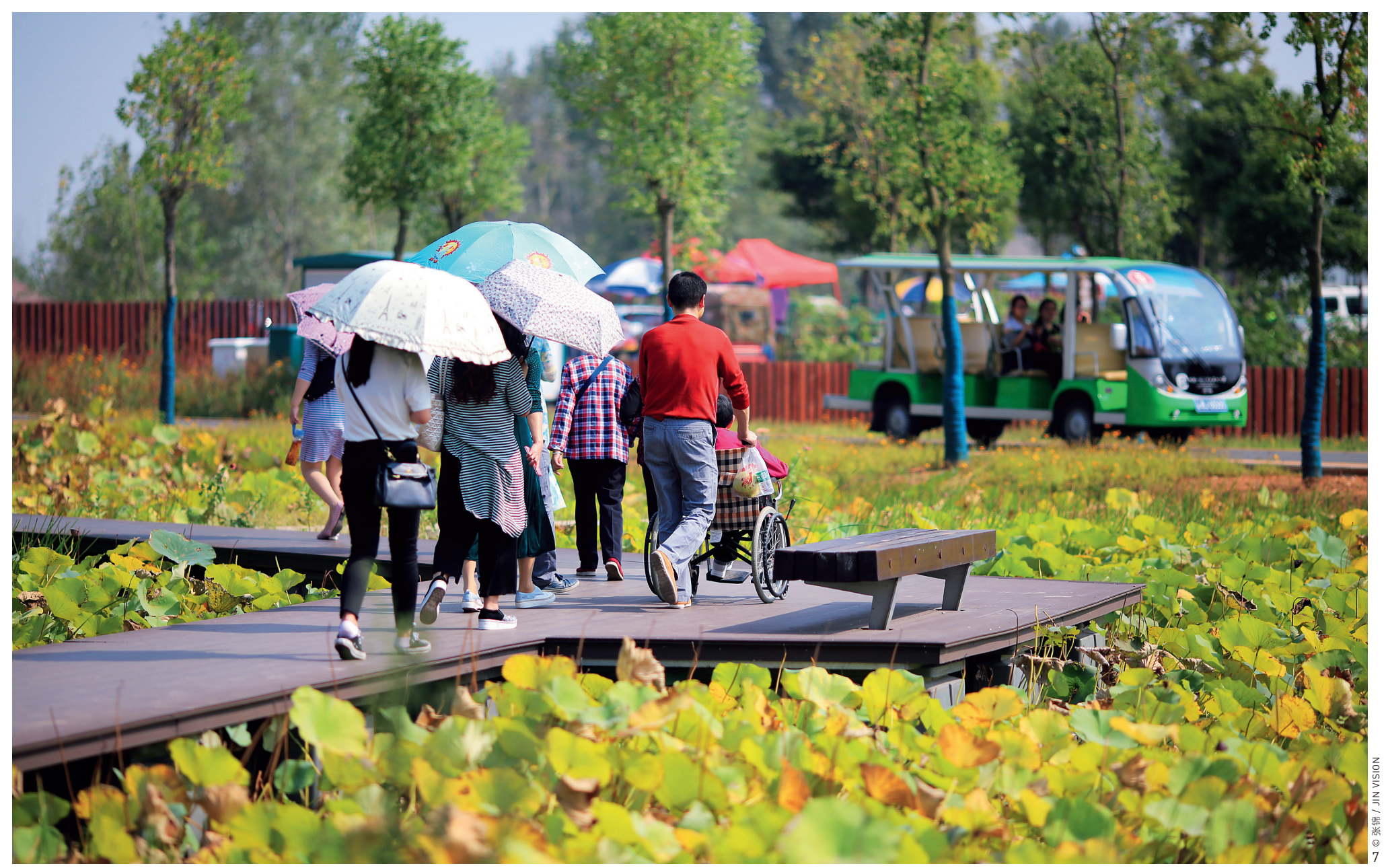

的、正上演着的农耕生产剧。慢跑、野餐、 散步等休闲活动也交织其中。城市游客能够 在这里观察和体验水稻种植及收割过程, 与 农民亲密接触, 体会劳作的艰辛与快乐。在 这一景观中, 劳作与休闲、生产与艺术、乡 村与城市、农民与游客相互融合, 营造出美 丽和谐的场景。

\section{4 连结过去与末来}

该项目将动态的农业生产过程作为景观 体验的一部分, 赋予埋没多年的城头山遗址 以新的生命力。规划方案不仅保证了古城遗 址的完整性与真实性, 还使场地发展为一处
集生态性、教育性、生产性及娱乐性于一体 的游览区。

得益于旅游业的发展, 遗址周边乡村获 得了相当显著的经济收益, 村民生活质量得 以提升。此外, 景区定期举办的大型活动, 如彩色跑、稻田彩绘节等, 也极大地丰富了 当地居民的文娱生活, 同时吸引了大量周边 城市游客前来参观体验。人们从这里了解自 己的祖先和食物来源, 赋予了遗址景观更多 的启发教育意义。

如今, 城头山国家考古遗址公园已经 成为常德市的一张新名片, 其追寻着历史回 忆, 以自身特有的景观语言, 重新勾画出人 对于土地的回望与依恋。LAF 


\section{Project Background}

Located in the core area of Chengtoushan Site in Lixian County of Changde City, Hunan Province, Chengtoushan National Archaeological Site Park becomes a national demonstration project of heritage site protection, cultural identity celebration, and tourism and recreation. This project includes a landscape design of the surroundings of the heritage site area of around $20 \mathrm{hm}^{2}$.

Chengtoushan was a hummock situated on an alluvial plain of the Dongtinghu Basin, where was characterized for the crop landscape before the heritage site was found in 1979. Soon after, the site was recognized as the earliest ancient Chinese city ever found, coupled with being famous as the birthplace of rice cultivation in China. However, the site protection policy of farming prohibition worsened the shortage of farmland resources. In 2014, after over 30 years of passive protection, the local government decided to transform the area into an attractive destination to boost local tourism and economy and to improve the wellbeing of local villagers.

\section{Challenges and Goals}

Before this project started in 2015, the farmlands around the Chengtoushan Site were replaced with avenues and squares of decorative landscapes. A museum sat on the central axis, and ornamental plants and flower beds were found everywhere. The incongruously large square, adjacent to the south entrance of the park, was under construction. There were also waterfront landscapes incongruous with the heritage site along the moat, including straight promenade, massive concrete platforms, pruned plants, and artificial ornamental stones. Worse, the water of some part of the moat suffered from heavy sedimentation and serious eutrophication, resulting in water bloom. Branch canals of the moat, constructed with hard stonework, blocked
8. 阶陌纵横的稻田博物馆

阳光透过玻璃廊桥酒在 稻田上。

10. 蜿蜒的玻璃廊桥可供游 客眺望古城遗址和周边 稻田景观。

8. The paths of the rice field museum

9. The sunlight goes through the glass bridge on the rice field.

10. The winding glass bridge allows visitors to overlook the heritage and surrounding rice field.

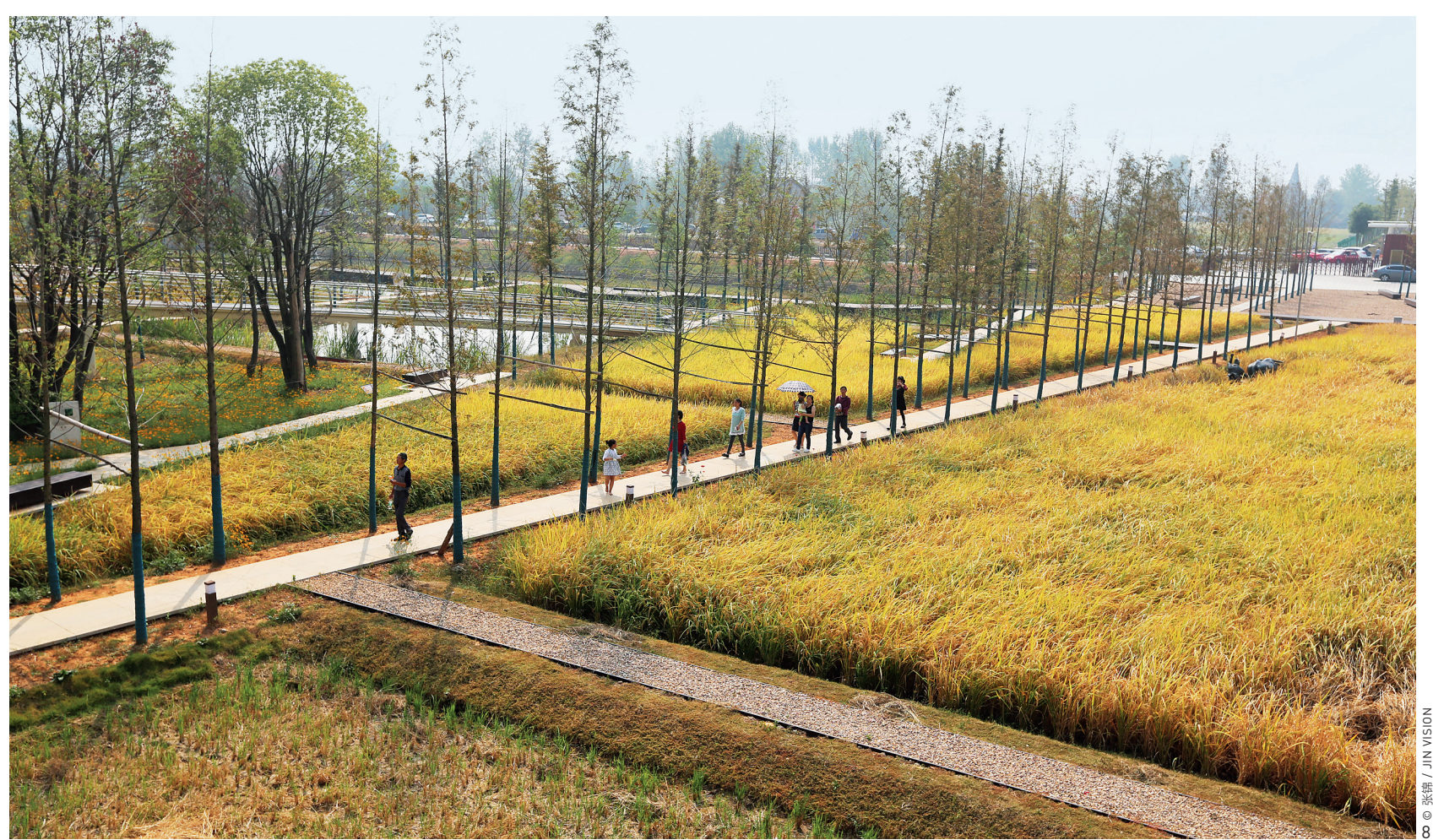




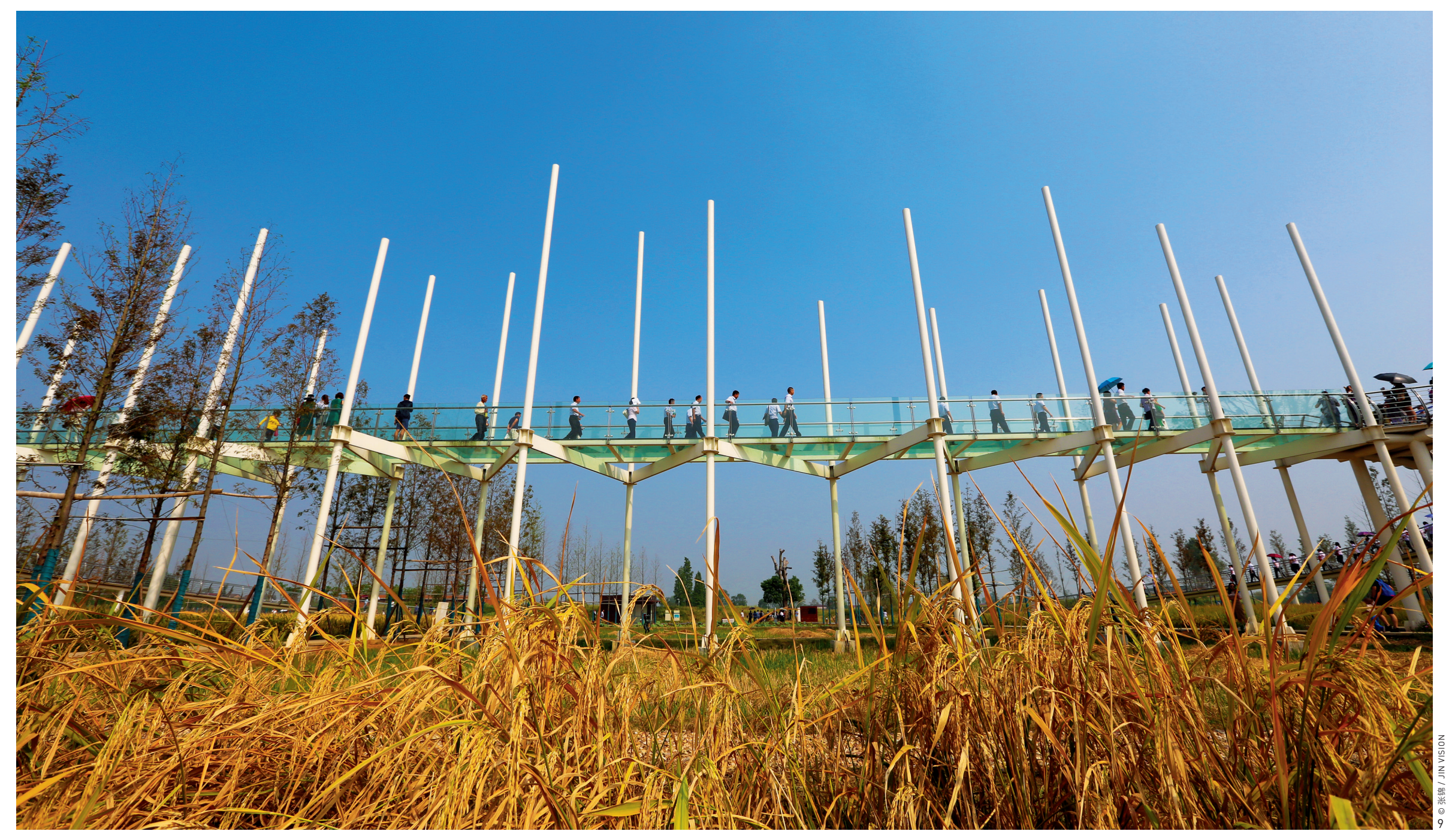

the water system. Consequently, it was difficult for the site without vitality to attract visitors.

The design team was commissioned to restore the moat waterfront and the landscape of the surroundings of the heritage site. Through a field research, the team found that the existing landscape avenue is hard to be transformed. However, it was feasible to redesign the square of the south entrance. In addition, most rice fields were remained and the soil was healthy that provided a possibility to restore the surrounding environment by reproducing the agricultural landscape. Thus, the primary challenge of the project was to protect the site, while transforming the site into a tourist destination by celebrating the local agricultural landscape. This project aimed to design an ecological and beautiful heritage park corresponding to its historic culture of the site.

\section{Design Strategies}

Diverse protection and design strategies were employed according to the specific condition of different areas in order to maximize the ecological, educational, productive, and recreational benefits.

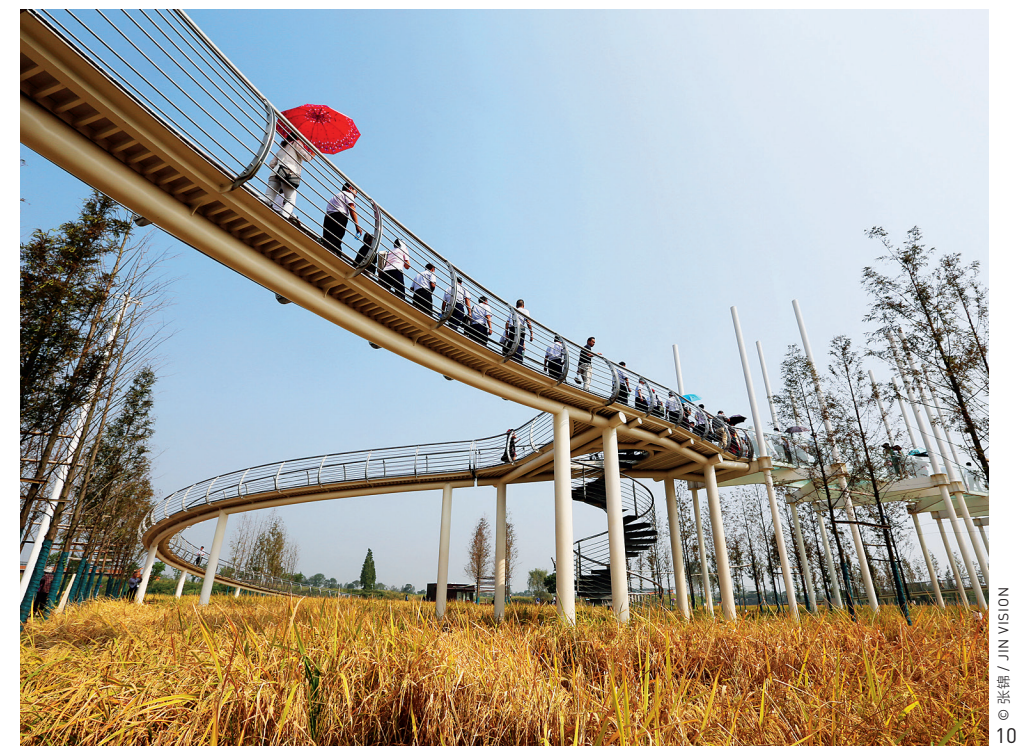




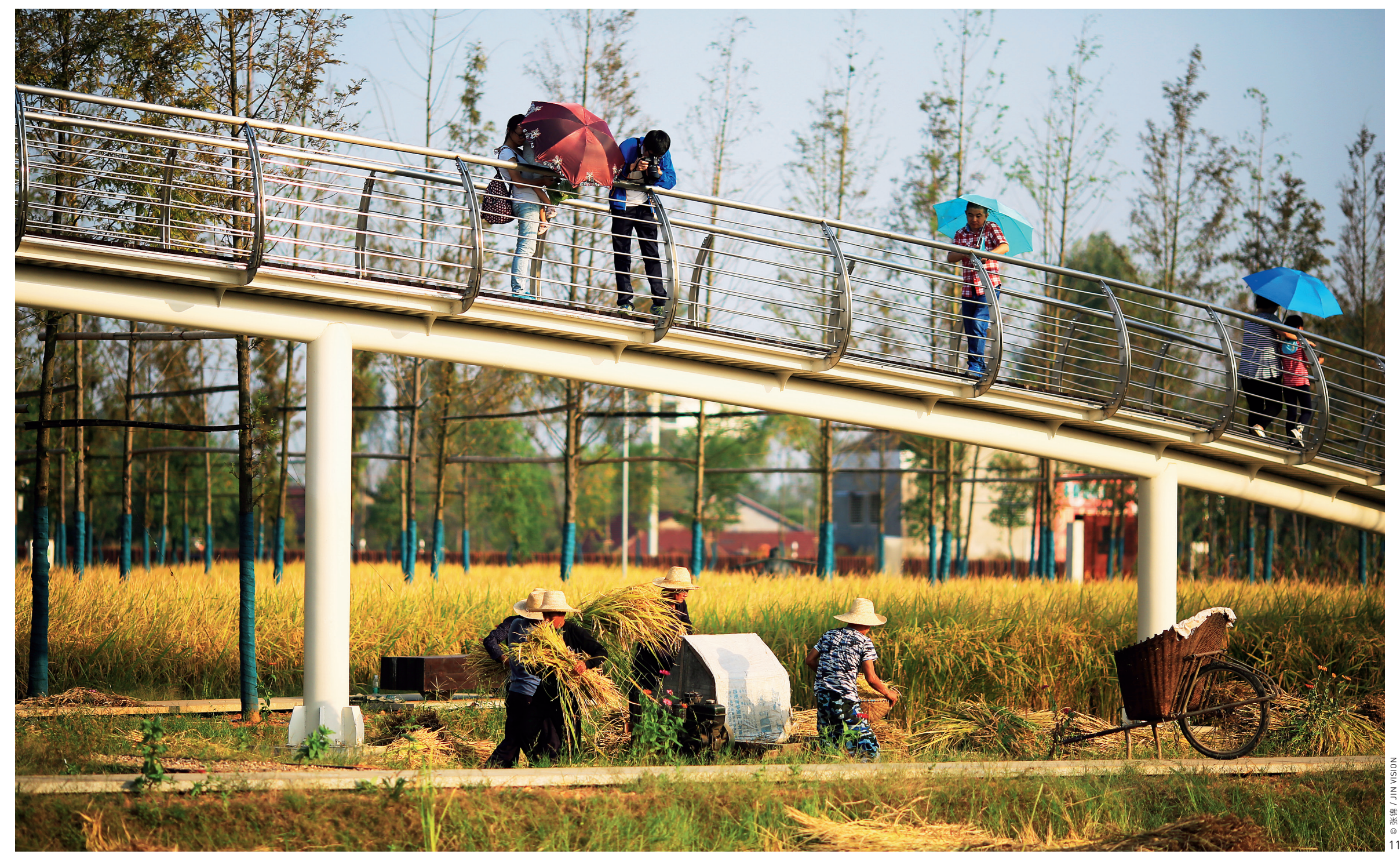

3.1 Ecological Restoration for the Moat Waterfront

The existing hardscape revetment was replaced with rip-rap and artificial timber piles, together with the technique of willow branch cutting, to protect the bank. A dozen of aquatic plant species, including reed (Phragmites australias), loosestrife (Lythrum salicaria), yellow iris (Iris pseudacorus), and great bulrush (Scirpus validus), were planted to create a phyto-purification system and a variety of habitats for aquatic creatures and insects. In the design, the waterfront consisted of rice fields, vegetation communities of productive aquatic plants, and wild grass patches, interspersed with sunken gardens and semi-open waterfront spaces, providing visitors diverse places to stop by, to observe the waterfowl, and to enjoy the sight of the heritage site. Along the revetment, the existing rice fields were preserved, while planting Chinese redwood (Metasequoia glyptostroboides) and Chinese tallow (Sapium sebiferum) in groves, not only

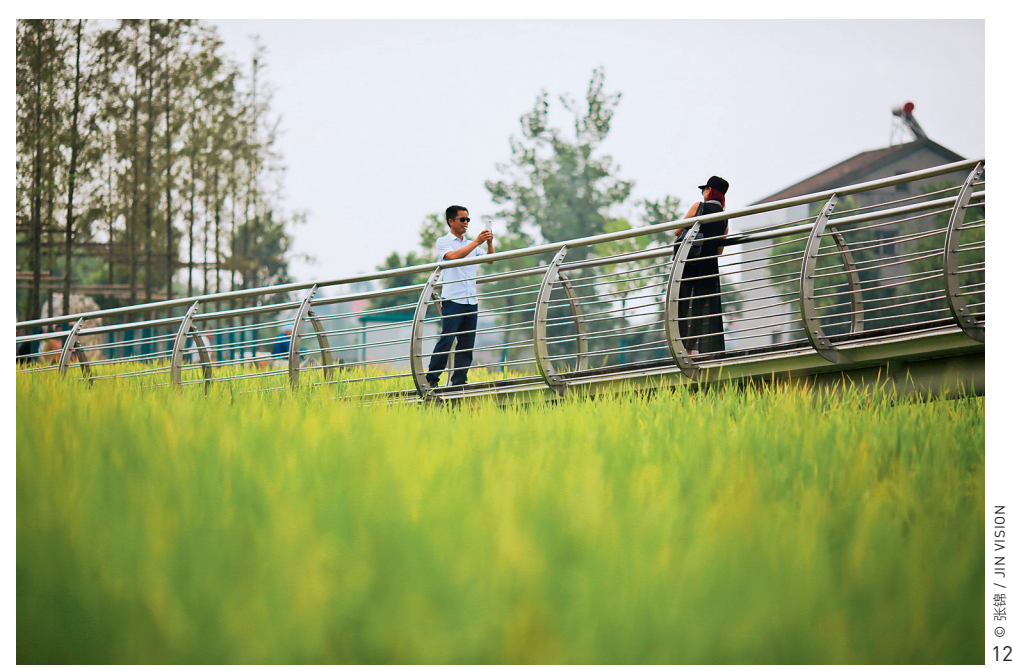


creating recreational spaces for visitors to experience in woodlands, but also buffering the site from the villages and farmlands to minimize disturbance caused by human activities.

To minimize the impact on the site, many assembled boxes were introduced to some parts of the moat course, through which an elevated wooden walkway, $30 \sim 50 \mathrm{~cm}$ above the water surface, was built. An interpretation system was also established along the trails. Surrounded by the moat, the heritage site looks like a tranquil ancient theater, which reminds visitors of its glory history.

\subsection{Rice Field Museum}

The design reproduced the rice field landscape into the square of the park's south entrance by innovatively creating a rice field museum, where a variety of rice crops - such as brown rice, fragrant rice, millet, glutinous millet, sago, barley, black rice, and red rice - can be cultivated and shown as "exhibits." The biodiversity of the farmland landscape was improved by creating aquatic habitats, including ponds, ditches, and wetlands, and productive native plants, such as lotus (Nelumbo nucifera), water chestnut (Trapa bispinosa), chufa (Heleocharis dulcis), cane shoots (Zizania latifolia), arrowhead (Sagittaria sagittifolia), and gorgon fruit (Euryale ferox) were introduced. These wetlands and water systems perform like sponges which collect rainwater, maintain water level, and absorb and filter pollutants. In addition, the direction of the field ridges were subtly designed to form a strong perspective scene. Chinese redwood trees were planted only in north-south, which both provides shade to visitors and makes the square a focus guiding people to explore the park.

In the rice field museum, a 4-meter high elevated glass bridge was built, from which visitors can overlook the heritage site in the north. The bridge floor made of glass allows sufficient sun light to the crops under the bridge, while creating a wonderful experience of walking on the bridge and overlooking the farmland through the glass. Ramps extended from the bridge in four different directions were designed to further stabilize the bridge itself and to enhance its connectivity with the surrounding rice field ridges. The museum is exactly like a living theater where unpretentious agricultural activities, such as planting, weeding, and harvesting, become attractions. City dwellers visiting the museum can watch and participate in farming practice, and jugging, picnics, walking, and other leisure activities are also allowed, where farming and recreation, production and art, rural and urban, farmers and tourists all exist in a harmonized way.

\section{Linking Past and Future}

The project activates the Chengtoushan Site by introducing dynamic agricultural activities into the landscape, which not only protects the heritage, but also develops the site into a destination with ecological, educational, productive, and recreational attractions.

The local tourism and the villagers' wellbeing have been greatly benefited due to the landscape restoration. In addition, scheduled events and programs, such as Color Run and Rice Field Painting Festival, not only enrich villagers' recreational and cultural life, but also provide educational opportunities to city visitors to learn the agricultural history and food production.

Nowadays, Chengtoushan National Archaeological Site Park creates a new image for the Changde City, redefining the relationship between human and land with its vernacular landscapes which celebrate the local cultural history of thousands of years. LAF

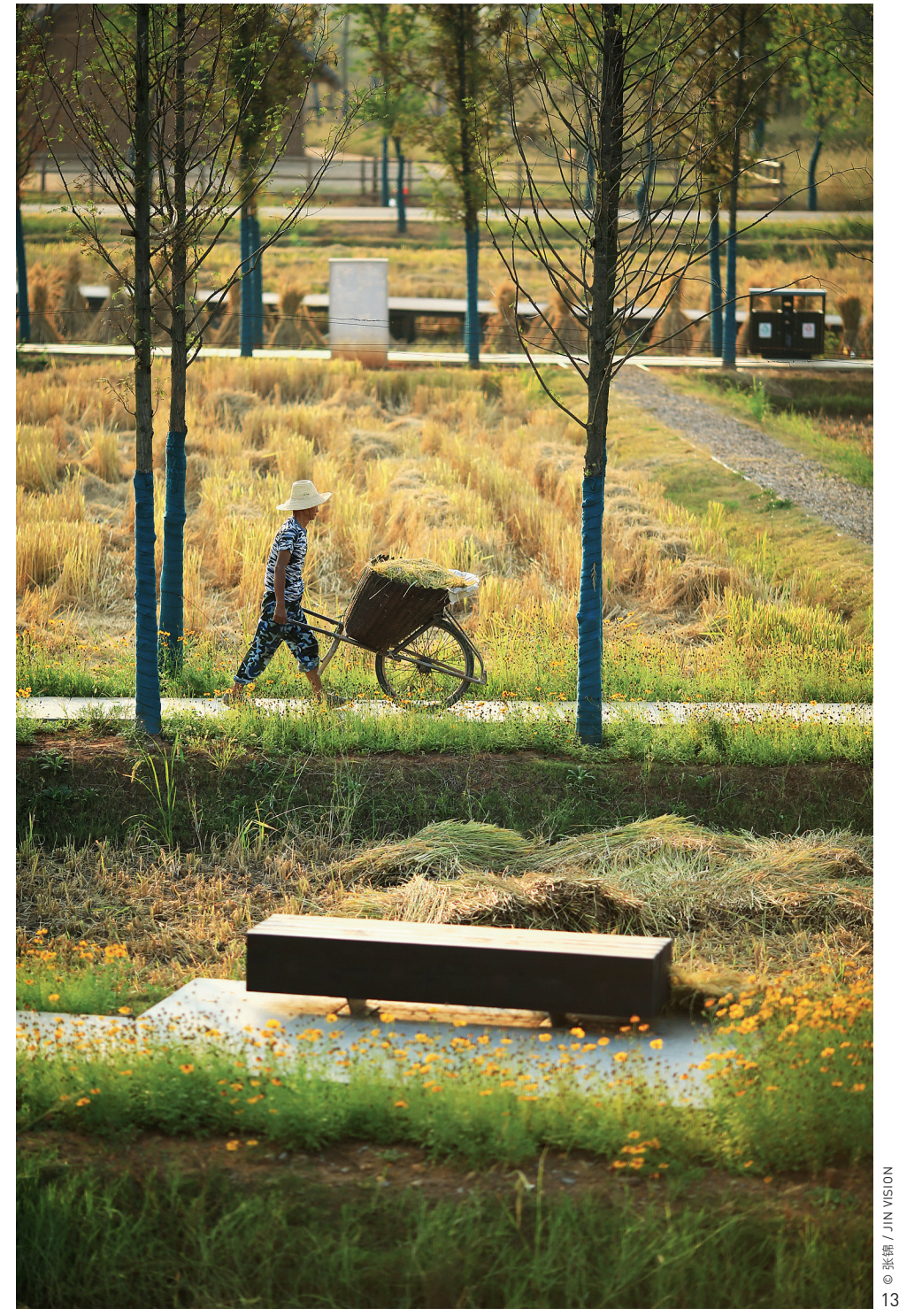

11. 廊桥上的游客现看进 行中的农耕活动。

12. 游客在嫩绿的稻田中 拍照

3. 推着手推车运送水稻 的农民
11. Visitors on the bridge are watching activities of agricultural production

12. Visitors are taking photos in the rice field.

13. A famer carrying the harvested rice with a cart 